This is an open access article under the CC BY-NC-ND license (https://creativecommons.org/licenses/by-nc-nd/3.0/) Issue III, November 2020

ISSN 2707-9481

ISBN 978-601-323-207-2

https://doi.org/10.31643/2020.008

\author{
Aizhan Yunussova \\ Abai KazNPU, Kazakhstan \\ E-mail: aizhan0296@mail.ru \\ ORCID ID 0000-0002-5076-4637
}

\title{
Formation model of management culture of future teachers-managers
}

\begin{abstract}
The main purpose of the article is to analyze the factors that predetermine the formation of management culture in the context of improving modern education, and their main characteristics. During the development of the model, the author focuses on the formation of managerial competence in the forms of humanities education technology in the formation of three areas of training for managerial activity: target, educational, action and practical. Each of them offers the formation of appropriate values for students of pedagogical universities. The author concludes that every child must have an education, as high as possible, so the quality of education will improve only if the education system is led by a strong, intelligent, educated and skilled, and most importantly, a highly cultured leader.

Keywords: teacher-psychologist, model, motivation, management, formation.
\end{abstract}

Cite this article as: Yunussova A. (2020), Bolaşaq menedjerdiñ basqaru mädenïetin qalıptastıru modeli [Formation model of management culture of future teachers-managers ], Challenges of Science. Issue III, 2020. Pp.: 52-58. https:// doi.org/10.31643/2020.008

\author{
Айжан Юнусова \\ Абай атындағы ҚазҰПУ \\ E-mail: aizhan0296@mail.ru \\ ORCID ID 0000-0002-5076-4637
}

\section{Болашақ менеджердің басқару мәдениетін қалыптастыру моделі}

\begin{abstract}
Абстракт: Қазіргі білім беруді жетілдіру жағдайында басқару мәдениетінің қалыптасуын алдын ала анықтайтын факторларды талдап, олардың негізгі сипаттамалары мақалада зерттеудің негізгі мәні болады. Автор модельді жасау барысында гуманитарлық білім беру технологиясының нысандарында басқарушылық құзыреттілікті қалыптастыру басқарушылық қызметке дайындықтың мақсаттық, білім беру, іс-әрекеттік және тәжірибеден тұратын үш саласын қалыптастыруға бағыттайды. Олардың әрқайсысы педагогикалық жоғары оқу орны студенттері үшін тиісті құндылықтарды қалыптастыруды ұсынады. Автор әрбір бала міндетті түрде білім алуы тиіс, мүмкіндігінше жоғары, сондықтан білім беру саласын мықты, зиялы, білімді де білікті, ең бастысы мәдениеті жоғары жетекші басқарғанда ғана білім сапасы жоғарылайды деп қорытындылайды.
\end{abstract}

Түйін сөздер: педагог-психолог, модель, мотивация, менеджмент, қалыптастыру.

Кіріспе. Соңғы жылдарда реформа барлық деңгейлерге және ең алдымен білім беру үдерісін басқаруға басымдық берілетін ұлттық жоба ретінде қаралған білім беруді жаңғырту проблемалары aca өзекті болуда. Кәсіптік білім беруді модернизациялау, бұл кәсіби біліктілігін және кәсіптікпедагогикалық мәдениетті ұдайы жетілдіру арқылы тиімді басқаруға қабілетті, бәсекеге қабілетті және кәсіби мобильді жоғары білікті маман дайындауды қамтиды. Демек, болашақ білім беру ұйымдары жетекшісінің басқару мәдениетін қалыптастырудың өзектілігі қазіргі әлеуметтікэкономикалық жағдай тұрғысынан оқу орнында орын алатын процестерді басқарудың балама педагогикалық жүйелерін енгізудің объективті қажеттілігімен анықталады.

«Қазақстан-2050» стратегиясында «білім беру саласындағы менеджменттің аз дамығандығы, оны дамыту қажеттілігінің» көрсетілуі (Қазақстан Республикасының Президенті Н.Ә.Назарбаевтың Қазақстан халқына жолдауы «Қазақстан жолы - 2050, 2014), Қазақстан Республикасында білім беруді дамытудың 2016-2019 жылдарға арналған мемлекеттік бағдарламасында «...қазіргі қоғамның басты талаптарының бірі - басқарушылық құзыреті дамыған жаңа тұрпатты адамды қалыптастыру» екендігіне аса мән берілуі қазіргі өмір талабынан шыққан өткір мәселе (Қазақстан Республикасында 
білім беруді және ғылымды дамытудың 2016-2019 жылдарға арналғанмемлекеттік бағдарламасы, 2016). Психологиялық-педагогикалық, әлеуметтану және басқа да әдебиеттерді талдау кәсібипедагогикалық мәдениетті қалыптастыру, оның ішінде оның басқару компонентінің мәселелерін зерттеулер. В. Н. Ахименко, Е. В. Бондарева, С. Е. Джаджа, И.Ф. Исаев, Г. Матеев, Н. С. Речкин, В. А., Сластенин, М. Р. Арпентева, Б. Трийено, Б. К. Кенжалиев, М. Атаева, Ч. Фаузи, С. Лавриенко және т.б. ғалымдардың жұмыстарынан орын алғанын көрсетеді, онда басқарудағы тұлғаның рөлі, оның маңызды сипаттамалары, сондай-ақ басқару қызметінің мазмұны мен тиімділігін анықтайтын факторлар талданады.

Басқару мәселесінің ежелгі грек философтарынан бастап, түркі ғұлама ойшылдарының еңбектерінде қарастырылғаны туралы, олардың құнды жазбаларындағы мемлекеттік басқарушының рөлі, ізгілікті басқару, басқарудың адамгершілік қағидалары жайлы ой-пікірлерін топтастыру, жіктеу мәселелері С. Қ. Қалиев, С. А. Ұзақбаева, А. Н. Көшербаева, Ұ.М.Әбдіғапбарова және т.б. ғалымдар еңбектерінде көрініс алған.

Болашақ оқытушы менеджерлердің мәдениетін қалыптастырудың моделі. Болашақ менеджелердің басқару мәдениетін қалыптастырудың мазмұнын жасау мен оны нәтижелі жүзеге асыру үшін алдымен оның құрылымдық-мазмұндық моделін жасап алу қажет. Өйткені, ол бізге осы қалыптастырудың құрамдас бөліктерін анықтауға, технологиясын жасауға, ұйымдастыру кезеңдері мен формаларын, әдіс-тәсілдерін, өлшемдері мен көрсеткіштерін айқындауға, диагностикалық құралдарын таңдауға және олардың барлығын бір құрылымға жинақтап, оған сәйкес жүйелі іске асыруға мүмкіндік береді. Осы тұрғыдан біз қалыптастыру, модель түсініктерінің мәнін қарастырамыз

Ғылыми әдебиеттерде қалыптастыру ұғымы «белгілі бір пішін беру, бір нәрсені толықтыру», «әртүрлі факторлардың ықпалында жеке тұлғаны қалыптастыру»; нәтиже (тұрақтандырудың кейбір деңгейі, нысанды игеру, жеке тұлғаның қасиеттері); сыртқы және ішкі факторлардың (білім беру, оқыту, әлеуметтік және табиғи орта, өз іс-әрекеті) әсерінен тұлғаны дамыту үдерісі тұрғысынан қарастырылған (Коджаспирова, 2000).

Біздің түсінігімізде «қалыптастыру» тікелей әсер ету ғана емес, сонымен қатар білім беру үдерісі субъектілерінің басқарушылық ұстанымдары, яғни басқару құзыреттілігі арасындағы диалогқа дайындықты қалыптастыру үшін студентті белгілі бір нысандармен және іс-әрекет шарттарымен қамтамасыз ету.

Әртүрлі ғылыми проблемаларды шешу, білім беруде жаңа ақпараттар алу, зерттеу жүйелерін, құбылыстарды, үдерістерді негіздеу барысында модельдеу әдісі жиі қолданылады. Модельдеу шындықты зерделеудің кең таралған ғылыми әдістерінің бірі және жалпыланған және дерексіз объект, зерттелетін құбылыстың сұлбасы ретінде оның құрылысын білдіреді. Соңғы жылдары модельдеу әдісінің ғылым мен тәжірибенің көптеген салаларында кеңінен қолданылатындығын Ю.К.Бабанский, А.Н.Беляева, В.П.Беспалько, Н.Д.Хмель және т.б. еңбектер дәлелдейді. Ю.К.Бабанскийдің пікірінше, модельдеу зерттелетін үрдіс немесе құбылыс туралы білімді жүйелеуге көмектеседі, олардың тұтас сипаттамаларының жолдарын болжайды, компоненттер арасындағы толық байланыстарды анықтайды, біртұтас жіктемесін жасау үшін мүмкіндіктер ашады (Исаева, 2003). Егер объектіні зерттеу мүмкін емес немесе қиын болса, онда модельдеу қажет. Философияда «модельдеу» адам танымының тәсілдерінің (әдістерінің, тәсілдерінің, жолдарының) бірін сипаттайтын ең маңызды санат ретінде ерекшеленеді.Психологияда модельдеу - шындықты зерттеудің кең таралған ғылыми әдістерінің бірі және жалпыланған әрі дерексіз объектінің құрылысы, зерттелетін құбылыстың схемасы. Бұл объект зерттеу үлгісі болып саналады (Умирбекова, 2010).

Модель - физикалық объектілер мен жағдайлардың тиісті таңдаулы маңызды аспектілерін қамтитын күрделі нысандардың оңайлатылған сипаттамасы. Модельдеу - модельдерді құру және зерттеу әдісі, педагогикада кең таралған, себебі, педагогикалық объектілер басқалардан өзіне тән күрделілігімен ерекшеленеді.

Н.В. Кузьмина модельдеуді педагогикалық ісәрекетті талап ететін объект тұрғысынан қарастырады. Педагогикада модельдеу өздерінің күрделілігі мен көлеміне байланысты зерттеу және өндіріс түрінде қиындық тудыратын объектілерді жақындастыруды білдіреді. Модельдеу әдісі диаграммалардың, суреттердің және қысқаша ауызша сипаттамалардың көмегімен кіріктірілген динамикалық жүйе түрінде педагогикалық феноменді бейнелеуге мүмкіндік береді. Педагогикалық жүйенің моделін құру - педагогикалық теория мен тәжірибе арасындағы байланыс, зерттелетін құбылыс саласындағы теориялық тұжырымдардың толықтығын тексерудің тиімді құралы (Кузьмина, 1985). Модельді құру - жалпы және бірлік арасындағы байланыстың жалпы ғылыми принципін 
нақтылау, онда олардың жаңа сапасын құру кезінде пайда болатын араласуы мен өзара әрекеттесуінен жаңа модель пайда болады. Бұл модель маңызды теориялық және әдіснамалық түсініктемелерді талап етеді, ондай болмаған жағдайда оның сипаттамасы өмір тіршілігіне қатысы жоқ, жай ғана сұлбаға абстракцияға айналуы мүмкін.

Педагогика саласында модельдің мінез-құлық жүйесіне тән «ерекшеліктер жүйесін» қамтитын стандартты түрі бар. Екінші түрі - құрылым ретіндегі модель; іс-қимыл, құрылатын үдерістің жұмыс істеуін және дамуын қамтамасыз ететін механизм.

Болашақ менеджерлердің басқару мәдениетін қалыптастырудың ерекшеліктері оның құрылымдық компоненттері, басқару мәдениетінің мазмұны, осы модельдің тиімділігін қамтамасыз ететін механизмдер, қағидалар мен технологиялар екінші типті модельді пайдалануды талап етеді. Біз болашақ менеджерлердің басқару мәдениетін қалыптастыру үшін модель әзірлеу кезінде педагогика ғылымында негізделген модельдеу принциптерін басшылыққа алдық.

Соның ішінде, адами басымдықтар қағидаттарын, ізгілендіру тұжырымдамасын, оған сәйкес модельдің орталық бейнесі - адам тұлғасының дамуын, өзін-өзі дамыту қағидаларын негізге аламыз. Модельді жасауда динамикалық тұрғыдан икемді болуы ескеріледі, ол - өзгерістер енгізу, қайта құрылымдау, күрделендіру немесе жеңілдету, сондай-ақ зерттеліп жатқан құбылыстың белгілі бір аспектілерін нақты бөлу кезінде көрінетін модельдің мәнерлілігі мен айқындық принципін сипаттайтын көріну принципі, зерттеушінің жеке нанымынан зерттеудің дербестігінде көрінетін объективтілік принципінен көрінеді.

\section{Мақсаты:}

Басқару ерекшелігімен байланысты шешімдердің тиімділігін арттыру және шешімдер қабылдау үшін ЖОО жүйесіндегі менеджердің басқарушылық мәдениетін қалыптастыру

\section{Міндеттері}

\begin{tabular}{|l|}
\hline Өзін-өзі \\
жетілдіру \\
қажеттіліктері \\
мен \\
басқару \\
қызметін \\
сапалы орындау \\
\hline
\end{tabular}

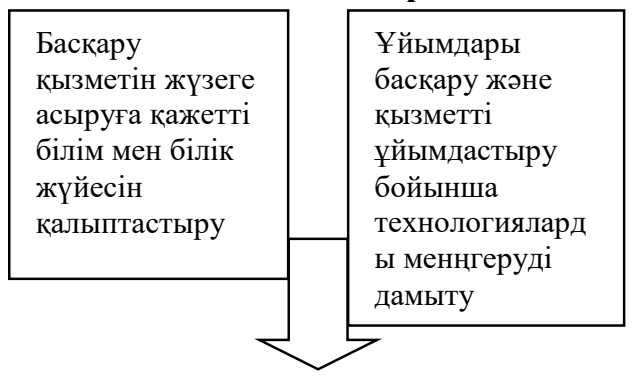

Кағадалары

\begin{tabular}{|l|}
\hline $\begin{array}{l}\text { Регионал } \\
\text { изация }\end{array}$ \\
\hline
\end{tabular}

\begin{tabular}{|l|}
\hline Бірлік \\
және \\
сабақтас \\
тық \\
\hline
\end{tabular}

\begin{tabular}{|l|}
\hline Ғыл \\
ыми \\
лыл \\
ық \\
\hline
\end{tabular}

\begin{tabular}{|l|}
\hline Басшыл \\
ықты \\
орталық \\
тандыру \\
\hline
\end{tabular}
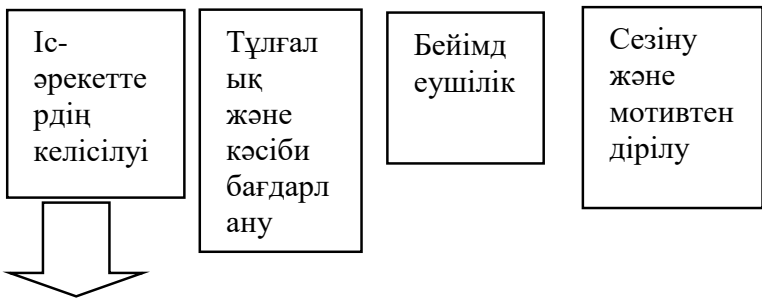

Басқару мәдениетінің компоненттері:
Күнделікті

басқару

қызметі мен өз

әс- әрекеітіне

талдау жасауды

білу қыбілетін

дамыту

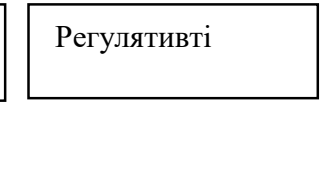

жүзеге асыра

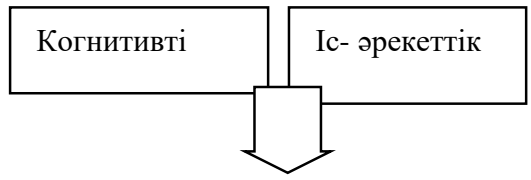

- Дайындықты ұйымдастырудың дидактикалық шарттарын анықтау

- Кәсіптік даярлықтың дидактикалық шарттарын жүзеге асыруды қамтамасыз ететін оқыту құралдарын анықтау.

- Кәсіби дайындық формаларын әзірлеу.

- Менеджердің ұйымдастыру-басқару мәдениетінің қалыптасу деңгейін анықтау критерийлерін әзірлеу.

- Кәсіби даярлықтың әлеуметтік-мәдени саладағы өзгерістерге сәйкестігін қамтамасыз ететін механизмдеріні қалыптастыру.

Сурет 1. Қалыптастыру моделін іске асыру технологиясы ЖОО жағдайындағы болашақ менеджерлердің ұйымдастыру-басқару мәдениеті 
Модельді жасау барысында гуманитарлық білім беру технологиясының нысандарында басқарушылық құзыреттілікті қалыптастыру басқарушылық қызметке дайындықтың мақсаттық, білім беру, іс-әрекеттік және тәжірибеден тұратын үш саласын қалыптастыруға бағытталған. Олардың әрқайсысы педагогикалық жоғары оку орны студенттері үшін тиісті құндылықтарды қалыптастыруды ұсынады. Біз ұсынған болашақ менеджердің басқару мәдениетін қалыптастыру моделі келесі мақсаттық, технологиялық, өлшемдік және пайымдастырушылық бөліктерді қамтиды:

Мақсаттық құрамдас бөлікті бөлу қажеттілігі мұғалімнің қызметіндегі саналы мақсат әдістерді, әрекеттерді басқару құралы ретінде таңдауды, әрекеттердің нәтижелерін болжанған нәтижемен салыстыра отырып анықтайтындығына байланысты. Бұл блокқа жүйеге кіретін барлық басқа компоненттер бағындырылады. Технологиялық - болашақ педагогтардың басқару құзыреттілігін қалыптастырудың мазмұны мен әдістерін, формалары мен құралдарын көрсетеді. Мазмұндық блок қажетті білімді, білік пен дағдыларды қамтиды, мақсатқа жетуге мүмкіндік береді. Мақсаттық жұмыстың табыстылығы мен тиімділігі (нәтижелілігі) бастапқы ұстанымдардан яғни негіз ретінде қабылданған принциптерден талап етіледі. Өлшемдік - болашақ педагогтардың басқарушылық құзыреттілігін қалыптасуын, оның динамикасын айқындауға арналған өлшемдер, көрсеткіштер мен деңгейлерді қамтиды. Зерттеу барысында болашақ педагогтардың басқарушылық құзыреттілігін осы аталған өлшемдік белгілерін айқындап алуға талпындық. Ол үшін біз болашақ педагогтардың басқарушылық құзыреттілігі қалыптасуының құрамын төрт компонентке сәйкес анықтадық: мотивациялыққұндылықты, когнитивтік, іс-әрекеттік және бағалаушылық-нәтижелік.

Мотивациялық-құндылықты - гуманды басқарушылық құндылықтарға сәйкес іс-әрекеттің тұрақты мотивтерін қалыптастыруды қарастырады (басқарушы рөлін психологиялық күйі тұрғысынан қабылдау; білім беру субъектілерімен өзара әрекеттесуге ұмтылушылық; сынып ұжымын, оқушының жеке-тұлғасын дамытуды, оқу-тәрбие үдерісін басқаруға өзінің тілегінің болуы және т.б.).

Когнитивтік - студенттердің басқарушылық құзыреттіліктерін танытуға қажетті әлеуметтіксаяси, экономикалық және психологиялық-педагогикалық білімдерін қалыптастыруды, сонымен қатар ойлау дағдысын дамытуды көздейді (Касымова, 2018). Осы компонент кәсіби педагогикалық міндеттермен қатар және менеджерлік саладағы міндеттерді шешу барысында кәсіби және арнайы меңгерген білімдерін пайдалана алу іскерліктерін кіріктіретін әдіснамалық, теориялық және технологиялық білімдердің бірлігін құрайды. Сондай-ақ, аталған қалыптастыру бойынша осы құрам педагогикалық жоғары оқу орнының студенттердің басқарушылық құзыреттілігін қалыптастыруға мүмкіндік беретін ақпараттық білім беру ортасын құруға мүмкіндік береді.

Ic-әрекеттік-болашақ педагогтар басқарушылық құзыреттілігін танытуға, практикалық ісәрекетке, жылдам шешім табуға қабілеттілігін, тәуекелге баруға қабілеттілігін көрсетуге мүмкіндік беретін жағдайларды қарастырады. Кәсіби жағдаяттарда басқарушылық құзыреттілігін қолдану іскерліктері мен өздігінен білім алу әрекетін, өзін-өзі дамытуын жүзеге асыруын көрсетеді; білім беру субъектіліерімен өзара белсенді әрекеттестігін қамтиды, бұл жағдайда білім беруші мақсатын, міндеттерін анықтайды, білім алушының танымдық ісәрекетін белсендіру үшін жағдай тудырады, кері байланысты жүзеге асыру үдерісіне бағыттайды, бақылайды, ынталандырады; білім алушыларға оқу ісәрекеті үдерісінде шешуге арналған кәсіби бағытталған проблемаларды көрсетеді. Осы компонент білім алушылардың кәсіби және өмірлік тәжірибесіне, олардың кәсіби басқару мотивациясына, ғылыми басқару жоспарларына, қызығушылықтарына, қажеттіліктеріне негізделеді. Бағалаушылық-нәтижелік - білім алушылардың өзіндік басқарушылық амал-тәсілдерін, ісәрекеттерін жете ұғынуын және өзінің басқару ісәрекеттеріне өзіндік талдау жасау мен өздігінен бағалауын, алынған нәтижелерді қойылған мақсаттармен біріктіруін танытады, білім беру субъектілерімен ізгілікті бағыттағы өзара әрекеттестік ке түсе алуын көздейді.

1. Мотивациялық-құндылықты өлшем - гуманды басқарушылық құндылықтарына оң қарымқатынасының болуы. Көрсеткіштері:

- менеджер рөлін жеке психологиялық күйі тұрғысынан қабылдауы;

- гуманды басқарушылық құндылықтарға, іс-әрекетке ұмтылуы;

- күрделі жағдайларда менеджер функциясын өзіне алуға тілегінің болуы;

- басқарушылық құзыреттілігін жеке жетілдіруі.

2. Когнитивтік өлшем - Педагог-менеджер, басқарушылық бойынша танымдық білімінің тереңдігі. Көрсеткіштері:

- басқарушылық құзыреттілік саласынан теориялық-әдіснамалық, арнайы білімінің болуы;

басшы, лидер ұғымдарының ұқсастықтары мен айырмашылығын білуі;

- басқарушылық құзыреттілігінің құрылымы мен мазмұнын меңгеруі; 
- педагог-менеджердің атқаратын қызметін, рөлін игеруі;

- басқарушылық құндылықтарды (эмпатия, рефлексия, толеранттылық, шеберлік және т.б.) мән-мағынасын жете түсінуі және т.б.

3. Іс-әрекеттік өлшем

- Басқарушылық құзыреттілігін таныта алуы. Көрсеткіштері:

- топқа ықпал ете алуы, топты соңынан ерте алуы;

- топтық іс-шараларда басқарушылық құзыреттілігін таныта алуы;

- сыни жағдаяттарда өздігінен шешім қабылдай алуы;

- өзіне жауапкершілік алып, проблемаларды өздігінен шеше алуы;

- жаңа идеяларды ойлап табуы.

4. Бағалаушылық-нәтижелік өлшем-өзінің басқару іс-әрекеттерін жете түсінуі мен өздігінен бағалауы, субъектілермен өзара әреккеттестіккке түсе алуы. Көрсеткіштері:

- рефлекцияға, сынға, өзін-өзі сынауға қабілеттілігі;

- өзінің басқару іс-әрекеттерін өздігінен талдауы;

- сыни жағдаяттарды талдай білуі, бағалай алуы;

- білім беру субъектілерімен өзара әрекеттестік ке түсе алуы;

- өзінің стратегиялық қырағылығын көрсете білуі.

Осы проблеманы зерттеудің теориялық және практикалық нәтижелерін қорытындылау болашақ педагогтардың басқарушылық құзыреттілігін қалыптастырудың үш деңгейін (жоғары, орта және төмен) көрсетуге мүмкіндік берді:

1. Төмен деңгей Басқарушылыққа, құндылықтарға қызығушылығы жоқ. Педагог-менеджер болуға ұмтылысы байқалмайды. Оны қажет етпейді Басқарушылық құзыреттілігі саласынан білімі төмен. Оның құрылымын, мазмұнын білмейді. Педагог-менеджердің құндылықтарын (эмпатия, рефлексия, толеранттылық, шеберлікжәне т.б.) білмейді. Топтық іс-шараларда, сыни жағдаяттарда басқарушылық таныта алмайды. Өздігінен шешім қабылдай алмайды. Өзінің басқарушылық ісәрекеттерін, амал-тәсілдерін талдауға ұмтылмайды, өздігінен бағалай алмайды. Басқару іс-әрекетінде білім беру субъектілерімен өзараәрекеттестікке түсе алмайды.

2. Орта деңгей Басқарушылыққа қызығушылығы бар болғанымен, құндылықтарға мән бермейді. Педагог-менеджер болуға талпынады, бірақ, оның маңызын, әлеуметтік мәнін түсінуі жеткіліксіз. Басқарушылық құзыреттілік түрлерін, құрылымын, мазмұнын біледі. Педагогменеджердің атқаратын қызметінен хабары бар. Педагог-менеджердің құндылықтарын (эмпатия, рефлексия, толеранттылық, шеберлік және т.б.) біледі. Бар түсініктерін күнделікті іс- әрекетте көрсете алмайды. Осы саладан практикалық іскерліктерді айтарлықтай біледі, бірақ тұрақты көрсете алмайды. Өзіне сенімділігі аз, сол себепті сыныпқа, оқу-тәрбие үдерісінің сапасын жақсартуға ықпал ете алмайды. Өздігінен шешім қабылдауға талпынады. Топта басқарушылық танытады. Топтық ісәрекеттерде ішінара жекелік таныта алады. Өзінің басқарушылық іс- әрекеттерін, амал-тәсілдерін ішінара түсінеді. Бірақ оларды талдау, бағалау барысында өзгелердің көмегіне сүйенеді.

3. Жоғары деңгей Басқарушылыққа, құндылықтарға қызығушылығы айқын байқалады. Оның қоғам сұранысынан, әлеуметтік тапсырыстан туындап отырғанын, мұғалім үшін мәнділігін толық түсінеді. Осы саладан тұрақты қызығушылығын, білімдерін таныта алады. Басқарушылық құзыреттілігі саласынан білімі жеткілікті. Басқарушылық құрылымын, мазмұнын, құндылықтарын жақсы меңгерген. Педагог-менеджердің атқаратын рөлін, қызметін толық біледі. Оларды практикалық, өмірлік іс-әрекеттерінде көрсетуге ұмтылады. Топтық іс- шараларда басқарушылығы анық көрінеді. Өзіне сенімді. Проблемаларды өздігінен шеше алады. Топқа ықпал ете алады, оларды соңынан ерте алады. Сыни жағдаяттарда басқарушылығын батыл, ерік-жігерімен танытады. Жаңа идеялар ойлап таба алады. Өзінің басқарушылық іс-әрекеттерін жете түсінеді. Сыни жағдаяттарда басқарушылық амал-тәсілдерді қолданады. Оларды өздігінен талдайды және бағалайды. Басқару ісәрекетінде субъектілермен өзараәрекеттестікті анық көрсетеді. Өзінің ізгілікті бағытын, стратегиялық қырағылығын көрсете біледі. Ал енді, модельдің келесі бөлігі ол - ұйымдастырушылық. Мұнда педагогикалық іс-әрекеттегі студенттердің басқару құзыреттілігін қалыптастыруда оны жүзеге асырудың педагогикалық шарттарының маңызды екендігі көрсетіледі. Бұдан басқа, аталған қалыптастыруды ұйымдастыру кезеңдерін, мазмұндық блокты даярлау жұмыстарын, эксперимент субъектілерін анықтауды қамтиды.

Педагогикалық, психологиялық, әлеуметтану әдебиеттерін талдау жетекшінің қызметі мен тұлғасын ғылымның әр түрлі саласындағы зерттеу объектісі ретінде көрсетеді. Ғалымдардың табысты тиімді жетекшінің портретін құраушы табуға ұмтылысы ортақ болып табылады. Отандық психолог-зерттеушілердің жұмыстарында А. Г. Ковалева және В. Н. Мясищева басшының күрделі 
қызметі істі, интеллектінің жоғары деңгейін, атап айтқанда, байқағыштықты, ақыл - ойдың икемділігін, шығармашылық бастаманы, жеке тұлғаның белгілі бір сипаттық қасиеттерін-іспен әуестенуін, оған жауапты қарым-қатынасын, адамдардың білімі мен оларға шебер көзқарасты, ерікжігері мен қаттылығын білуді талап етеді. Ғылыми жетекшінің ұйымдастырушылық қабілеттерінің маңызды құрамдас бөлігі ретінде ғалымдар нақты шындықты бағдарлай алу, адамдар мен олардың мүмкіндіктерін түсініп, өзіндік интегралды қасиеттерді бөліп көрсетеді: шығармашылық қиялмен (тапқырлық, өнертапқыштық) ұштасқан ақылдың икемділігі, ерік дамуында: батылдық, қаталдық т.б. (Ковалев, 1985).

Психолог Л. И. Уманский шебер ұйымдастырушының сапасын атап өтті: ақыл-ойдың практикалық, белсенділік, бастамашылдық, табандылық, өзін-өзі басқару, өз бетінше әрекет ету, жұмысқа қабілеттілік, бақылау, жалпылық, эмпатияға қабілеттілік, ұйымшылдық (Уманский, 1993). Психолог О. А. Кравченко адамдармен қарым-қатынаста және қызметте жеке тұлғаны дамыту қажет келесі басқарушылық қасиеттерді динамикада береді: мақсат қоя білу және жан-жақты басқару шешімдерін қабылдай білу; қойылған міндеттерді шешу үшін барабар құралдарды таба білу; құрастыра білу пікірлестер командасын жарқын тұлғаларды білу, біріктіру, олардың өзара келісім негізінде және интеллектуалдық бірлігі (Кравченко, 1997).

Қорытынды. Басқару мәдениеті - білім менеджерінің басқарудағы тиімді атрибуты және әрбір тұлға субьект-обьект қатынасында оның ықпалын сезінеді. Басқару мәдениеті-күрделі, көп қырлы, кешенді сипатқа ие құбылыс, білімді эффективті басқарушы менеджер тұлғасының мынандай қасиеттерін бөліп көрсетуге болады: тұлғалық, кәсібилік, мәдениеттанушылық (Юнусова, 2019). Тиімді басшы-жоғары деңгейдегі менеджер, ресурстардың ең аз шығындарының өзінде жоғары мақсатқа қол жеткізу дәрежесімен айқындалады. Қоғамның дамуы жағдайында әлеуметтік базаны кеңейту басқару мәдениетін қалыптастыру проблемасын тек қана маман - басқарушыда ғана емес, сонымен қатар болашақ менеджерлерге де қатысты қойды. Менеджердің басқару мәдениеті тек қана кәсіби менеджерде ғана емес, болашақ менеджерлерде де бөлек көрінбейді, ол маман - басқарушы тұлға мәдениетінің бір жағы ретінде әрекет етеді. Болашақ менеджерлердің басқару мәдениетін қалыптастыру кезінде мынадай факторларға сүйену қажет: ұлттық, әлеуметтік, мәдени - білім беру, кәсіптік білім беру, моральдық - адамгершілік.

Мақалаға сілтеме: Юнусова, А., (2020), Болашақ менеджердің басқару мәдениетін
$\begin{aligned} & \text { қалыптастыру моделі. Challenges of } \\ & \text { https://doi.org/10.31643/2020.008 }\end{aligned}$

\section{Қолданылған әдебиет тізімі}

Arpentieva, M. R., Kassymova, G., Kenzhaliyev, O., Retnawati, H., Kosherbayeva, A. (2019). Intersubjective Management in Educational Economy. Challenges of Science. https://doi.org/10.31643/2019.004

Arpentieva, M. R., Kassymova, G., Kenzhaliyev, O., Retnawati, H., Kosherbayeva, A. (2019). Intersubjective Management in Educational Economy. Challenges of Science. https://doi.org/10.31643/2019.004

Atayeva, M., Ciptaningrum, D. S., Hidayah, R., Kassymova, G. K., Dossayeva, S. K., Akmal, A. (2019). Cultivating Junior High School Students' Critical Thingking Skills by Using a Short Video in English Language Classroom. Bulletin the National Academy of Sciences of the Republic of Kazakhstan, 5(381), 57 - 69. https://doi.org/https://doi.org/10.32014/2019.25181467.124

Atayeva, M., Putro, N. H. P. S., Kassymova, G., Kosbay, S. (2019). Impact of reading on students' writing ability. Challenges of Science. https://doi.org/10.31643/2019.001

Fauzi, C., Basikin, Duisenbayeva, S., Kassymova, G. (2020). Exploring EFL Students Teacher Readiness and Gender Differences of Learner Autonomy. Bulletin the National Academy of Sciences of the Republic of Kazakhstan, 1(383), 288-299. https://doi.org/https://doi.org/10.32014/2020.2518-1467.34

Kassymova, G. (2018). Competence and its implications. Challenges of Science. https://doi.org/10.31643/2018.063

Kenzhaliev B.K., Kul'deev E.I., Luganov V.A., Bondarenko I.V., Motovilov I.Y., Temirova S.S. (2019). Production of Very Fine, Spherical, Particles of Ferriferous Pigments from the Diatomaceous Raw Material of Kazakhstan. Glass and Ceramics, 76(56), 194-198. https://doi.org/10.1007/s10717-019-00163-w

Lavrinenko S. V., Gorelova I. V., Kassymova K. G., Kubantseva O. V., Khudyakova T. L., Yusipova I. V., Arpentieva M. R. (2020). Problems of context and conceptual management in education: psychological, social and economical aspects. Bulletin the National Academy of Sciences of the Republic of Kazakhstan, 1(383), 264-276. https://doi.org/10.32014/2020.2518-1467.32

Triyono, B.M., Mohib, N., Kassymova, G.K., Pratama, G.N.I.P., Adinda D., Arpentieva, M.R. (2020). The Profile Improvement of Vocational School Teachers' Competencies. Vysshee obrazovanie v Rossii = Higher Education in Russia. Vol. 29, no. 2, pp. 151-158. https://doi.org/10.31992/0869-3617-2020-29-2-151-158

Исаева Т.Е. Педагогическая культура преподавателя как условие и показатель качества образовательного процесса в высшей школе (Сравнительный анализ отечественного и мирового образовательного процесса) / Т.Е.Исаева. — 


\section{Materials of International Practical Internet Conference "Challenges of Science”}

Ростов-на-Дону: Рост. гос. ун-т путей сообщения, 2003.- 312 с.

Ковалев А.Г., Мясищев В.И. Психологические особенности человека. Т.2. -Л., 1960.-286c.

Коджаспирова Г. М. Педагогический словарь: для студентов высш. и сред. пед. учеб. заведений / Г. М. Коджаспирова А. Ю. Коджаспиров. - М.: Изд. центр «Академия», 2000. — 176 с.

Кравченко О.А. Организационно-педагогические услови до профессиональной управленческой подготовки учащихся: дис. ... канд. пед. наук. - Брянск, 1997. - 88c. 90.

Кузьмина Н.В. Способности, одаренность и талант учителя. -М.: Знание, 1985. — 32 с.

Қазақстан Республикасында білім беруді және ғылымды дамытудың 2016-2019 жылдарға арналғанмемлекеттік бағдарламасы. - Астана, 2016, - 1 наурыз

Қазақстан Республикасының Президенті Н.Ә.Назарбаевтың Қазақстан халқына жолдауы «Қазақстан жолы - 2050: Бір мақсат, бір мүдде, бір болашақ». - Астана, 2014. - 17 қаңтар.

Уманский Л.И. Психология организаторской деятельности школьников.- М., 1993.- 171 с.

Умирбекова Ж.Б. Организационно-педагогические основы менеджмента в образовании в условиях глобализации современного общества: автореф. ... док. пед. наук. - Атырау, 2010. - 46 с.

Юнусова, А., (2019) Болашақ менеджерлердің басқару мәдениетін қалыптастыру. «Ғылымның өзекті мәселелері»Халықаралық практикалық интернет- конференция материалдары / Materials of International Practical Internet Conference "Challenges of Science". Басылым II, б.: 20 - 24. https://doi.org/10.31643/2019.003

\section{Refrences}

Arpentieva, M. R., Kassymova, G., Kenzhaliyev, O., Retnawati, H., Kosherbayeva, A. (2019). Intersubjective Management in Educational Economy. Challenges of Science. https://doi.org/10.31643/2019.004

Atayeva, M., Ciptaningrum, D. S., Hidayah, R., Kassymova, G. K., Dossayeva, S. K., Akmal, A. (2019). Cultivating Junior High School Students' Critical Thingking Skills by Using a Short Video in English Language Classroom. Bulletin the National Academy of Sciences of the Republic of Kazakhstan, 5(381), 57 - 69. https://doi.org/https://doi.org/10.32014/2019.25181467.124

Atayeva, M., Putro, N. H. P. S., Kassymova, G., Kosbay, S. (2019). Impact of reading on students' writing ability. Challenges of Science. https://doi.org/10.31643/2019.001

Fauzi, C., Basikin, Duisenbayeva, S., Kassymova, G. (2020). Exploring EFL Students Teacher Readiness and Gender Differences of Learner Autonomy. Bulletin the National Academy of Sciences of the Republic of Kazakhstan, 1(383), 288-299. https://doi.org/https://doi.org/10.32014/2020.2518-1467.34

Kassymova, G. (2018). Competence and its implications. Challenges of Science. https://doi.org/10.31643/2018.063

Kenzhaliev B.K., Kul'deev E.I., Luganov V.A., Bondarenko I.V., Motovilov I.Y., Temirova S.S. (2019). Production of Very Fine, Spherical, Particles of Ferriferous Pigments from the Diatomaceous Raw Material of Kazakhstan. Glass and Ceramics, 76(56), 194-198. https://doi.org/10.1007/s10717-019-00163-w

Lavrinenko S. V., Gorelova I. V., Kassymova K. G., Kubantseva O. V., Khudyakova T. L., Yusipova I. V., Arpentieva M. R. (2020). Problems of context and conceptual management in education: psychological, social and economical aspects. Bulletin the National Academy of Sciences of the Republic of Kazakhstan, 1(383), 264-276. https://doi.org/10.32014/2020.2518-1467.32

Triyono, B.M., Mohib, N., Kassymova, G.K., Pratama, G.N.I.P., Adinda D., Arpentieva, M.R. (2020). The Profile Improvement of Vocational School Teachers' Competencies. Vysshee obrazovanie v Rossii = Higher Education in Russia. Vol. 29, no. 2, pp. 151-158. https://doi.org/10.31992/0869-3617-2020-29-2-151-158

Yunussova A., (2019). Bolaşaq menedjerlerdiñ basqarw mädenïetin qalıptastırw [Formation of management culture of future managers]. Materials of International Practical Internet Conference "Challenges of Science". Issue II, p.: 20 - 24. https://doi.org/10.31643/2019.003

Isayeva T.Ye. Pedagogicheskaya kul'tura prepodavatelya kak usloviye i pokazatel' kachestva obrazovatel'nogo protsessa v vysshey shkole (Sravnitel'nyy analiz otechestvennogo i mirovogo obrazovatel'nogo protsessa) [Teacher's pedagogical culture as a condition and quality indicator of the educational process in higher education] / Rostov-na-Donu: Rost. gos. un-t putey soobshcheniya, 2003.- $312 \mathrm{~s}$.

Kovalev A.G., Myasishchev V.I. Psikhologicheskiye osobennosti cheloveka [The psychological characteristics of man]. T.2. -L., 1960.-286s.

Kodzhaspirova G. M. Pedagogicheskiy slovar': dlya studentov vyssh. i sred. ped. ucheb. Zavedeniy [Pedagogical Dictionary: for students of higher. and wednesday ped textbook. institutions] / G. M. Kodzhaspirova A. YU. Kodzhaspirov. - M.: «Akademiya», 2000. - $176 \mathrm{~s}$.

Kravchenko O.A. Organizatsionno-pedagogicheskiye uslovi do professional'noy upravlencheskoy podgotovki uchashchikhsya [Organizational and pedagogical conditions before the professional management training of students]: dis. ... cand. ped. Sc., Bryansk, 1997. - 88s. 90.

Kuz'mina N.V. Sposobnosti, odarennost' i talant uchitelya [Abilities, giftedness and talent of a teacher]. -M.: Znaniye, $1985 .-32$ s.

State program for the development of education and science in the Republic of Kazakhstan for 2016-2019. - Astana, 2016, - March 1

Speech of the President of the Republic of Kazakhstan NA Nazarbayev to the people of Kazakhstan "Kazakhstan's way - 2050: One goal, one interest, one future." - Astana, 2014. - January 17.

Umanskiy L.I. Psikhologiya organizatorskoy deyatel'nosti shkol'nikov [Psychology of organizational activity of schoolchildren]. M., 1993.- $171 \mathrm{~s}$.

Umirbekova ZH.B. Organizatsionno-pedagogicheskiye osnovy menedzhmenta $\mathrm{v}$ obrazovanii $\mathrm{v}$ usloviyakh globalizatsii sovremennogo obshchestva [Organizational and pedagogical foundations of management in education in the context of the globalization of modern society: author.]: avtoref. ... dok. ped. nauk. - Atyrau, 2010. - $46 \mathrm{~s}$. 